\title{
THE MONTESSORI'S VALUES IN TEACHING ENGLISH TO YOUNG LEARNERS (TEYL)
}

\author{
Aprilian Ria Adisti \\ State Institute for Islamic Studies (IAIN) Salatiga \\ aprilian_adisti@yahoo.com
}

\begin{abstract}
ABSTRAK
Teaching English to Young Learner (TEYL) becomes so popular today since the needs of facing globalization era. The Montessori Method one of the best educational methods for children based on the child development theory of Dr. Maria Montessori. The essence of the Montessori Method is to make the child an independent learner. This research uses descriptive qualitative method which aims to describe the implementation of Montessori's values into Teaching English to Young Learners at Aisyiyah Kindergarten, Karanganyar. The subjects of this research are English teacher and 26 students in this school. Based on the results of the research, it was concluded that the application of Montessori's values in TEYL is able to increase students' interest and enthusiasm in learning English.
\end{abstract}

Keywords : Montessori Values, TEYL

\section{ABSTRACT}

Pengajaran Bahasa Inggris untuk anak-anak menjadi sangat populer saat ini karena kebutuhan dalam menghadapi era globalisasi. Metode Montessori merupakan salah satu metode pendidikan terbaik untuk anak-anak berdasarkan teori perkembangan anak oleh Dr. Maria Montessori. Inti dari metode Montessori adalah menjadikan anak sebagai pembelajar mandiri. Penelitian ini menggunakan metode deskriptif kualitatif yang bertujuan untuk mendeskripsikan penerapan nilai-nilai Montessori ke dalam pengajaran bahasa Inggris di TK Aisyiyah, Karanganyar. Subyek penelitian ini adalah guru bahasa Inggris dan 26 siswa di sekolah ini. Berdasarkan hasil penelitian, disimpulkan bahwa penerapan nilai-nilai Montessori pada pengajaran bahasa Inggris untuk anak-anak mampu meningkatkan minat dan antusiasme siswa dalam belajar bahasa Inggris.

Kata Kunci: Nilai-nilai Montessori, Pengajaran Bahasa Inggris untuk Anak-anak

\section{PENDAHULUAN}

Teaching English to Young Learners (TEYL) is becoming a trend for schools in Indonesia. Indonesia as one of developing country must prepare the young generations to be able to master the aspect of science and technology. Mastering English as global language is considered as the need in this era. Without it, people will get the problem in mastering science and technology also. Long time ago, English is taught for the first time to Senior High School level, but now, most of schools in Indonesia insert English as subject in curriculum even in early childhood level. Early childhood according to NAEYC (National Association for the Education of Young Children) in Aisha, (2011: 1) is the children who are in the age range $0-8$ years, which is included in educational programs in the park child care, child care in the family (family and child care home), education either private or 
public preschool, kindergarten, and elementary school.

Indonesia has a special law on national education systems, especially for early childhood. In that law is stated that early childhood education is education before primary education which is aimed to give the education to children from birth to the age of six years that is accomplished by providing stimulation of education to help the growth and development of the physical and spiritual so that children have readiness in entering further education.

Kindergarten level for some children is the first stage in learning through informal situation. Here, children learn how to interact with the knowledge and also social life. They learn everything surround them. Kindergarten is also the place to stimulate the children in developing their language skill. Learning English as the foreign language may be difficult for adult but not for children. Pinter (2006) confirms that young learners have a great curiosity to try new things and to explore concrete to abstract things. They enjoy learning through playing. If the learning is fun, automatically children language skill will develop significantly.

TK Aisyiyah is one of the Islamic kindergarten schools that are supervised by Indonesia Ministry of Religious Affairs. The main curriculum in this school is Islamic curriculum but national curriculum is also implemented. Moreover, English is one of extracurricular subject that also taught to the students. Teachers teach English with very simple material. The goal is to introduce English as communication language because they know that English is the most popular foreign language in this world. Learning English is one of the first experiences for students in learning foreign language since the role of English is as the first foreign language. As Ramelan states in Yulianti (2006:1), English is the first foreign language used in Indonesia that taken an important role to the development of science, culture, and bilateral relationship. Although English is introduced in this school, but the basic of this school is still teaching Islamic values.

Montessori Method is a method of learning that developed in the 19th century. This method is widely adopted by the Western method, especially for Childhood Education. The Montessori Method developed by Dr. Maria Montessori, is a child-centered educational approach based on scientific observations of children from birth to adulthood. She is the Italian woman who expert on Early Childhood Education. The Montessori Method emphasizes the liberty or freedom. The teacher, student, and environment create a learning triangle. The classroom is prepared by the teacher to encourage 
independence, freedom within limits, and a sense of order. The child, through individual choice, makes use of what the environment offers to develop him, interacting with the teacher when support and/or guidance are needed. Montessori's method has been time tested, with over 100 years of success in diverse cultures throughout the world. It proves that this method is one of the best methods especially to childhood education.

Hence, this research focuses to describe the implementation of Teaching English to Young Learners by adapting Montessori's values at TK Aisyiyah and also to analyze the strength and weakness in teaching and learning process.

\section{THEORETICAL REVIEW \\ Previous Study}

There are some the research had been found about Montessori values. Bathan and Olano study (2011) talked about personal development of young learners, where special educational materials were used to keep children interested to student and there was an emphasis on "practical life skills". The findings in this study provided insights of situation and ways of teaching learning that can be used to develop tools for evaluating and enhancing the implementation of Montessori's pedagogy in Montessori Schools. Meanwhile, Cauller's study (2011) conducted a study of
Montessori in reading, science and mathematics at any grade of age. It supported Montessori view of learning. The use of EEE model hypotheses was to identify and eliminate the model errors from the assessments. Furthermore, Bagby's (2010) study summarized many studies related to Montessori's approach. It was revealed that Montessori study has been used in many kinds of field studies in the world, the application is for both young and adult people. The use of Montessori's method here was to focus the result in diverse expertise; psychology, education, science, and medicine.

Comparing to the previous research above, the novelty aspects of this research are on the lesson of learning which only focus on teaching English. The other novelty aspects are the location of the research that is in Islamic Kindergarten TK Aisyiyah Karanganyar and the objects of the research are students from TK $A$ and $B$ level in the academic years of 2016/2017.

\section{The Montessori's Values}

The Montessori Method is an educational method for children based on the child development theory of Dr. Maria Montessori. She is an educator from Italy in the late 19th and early 20th centuries. This method is applied primarily in preschool and elementary schools, although there is be implemented to 
secondary level. Crain (2004) stated one underlying premise of the Montessori Method is that each child possesses an inner power that motivates them to seek out specific activities and interactions. Montessori developed a method of children's education by giving them the freedom to do activities and organize daily events. This method is known as the Montessori Method. Montessori argues that the application of modern scientific in education, especially by the movement of "Scientific Pedagogy" precisely fetter the development of the child's soul. This is our foundation in understanding how the nature of learning for children.

According to Montessori, the goal of education is "to be able to find activities that are so intrinsically meaningful that we want to throw ourselves into them". Montessori learning combines children of different ages and abilities into one class. The learning environment is arranged according to the child's body size, plays material sequentially from simple to complex, prepares direct experience in every child's activity by actively involving the child, and the teacher acts to guide and observe the child's developmental process rather than instructing. The lessons from the Montessori Method are more organized individually than the group. Schools that adapt the Montessori Method implement less individualized learning in children and are not planned for group activities. Children move and change game material freely throughout the room. The Montessori Method outlines three concepts as the key to learning:

a. The children learn when doing activities directly.

b. The children are free to choose what they need to develop ccompetence.

c. The teachers should not dictate learning goals to children so they can choose activities freely to get fun learning atmosphere.

The essence of the Montessori Method is to make the child an independent learner that means an independent child in learning. Children are developed according to their own ability. Therefore, since children doing learning activities, they should be the basis for directing them to become more independent. They learn actively based on their own volition and will according to their own desires.

\section{Teaching English to Young Learners (TEYL) using Montessori's Values}

Teaching English to Young Learners (TEYL) becomes so popular today since the needs of facing globalization era because of several reasons. First, it is often assumed that it is better to begin learning languages early (Y. Hu, 2007). Second, economic globalization has resulted in the widespread use of English and many governments 
believe it is essential to have an English speaking workforce in order to compete (Enever \& Moon, 2009). And third, parents want their children to develop English skills to benefit from new world orders and put pressure on governments to introduce English to younger's children (Brock-Utne \& Holmarsdottir, 2004). As mentioned in the background of the problem, English takes dominant role as an international language. Realizing how important the mastery of English in this era of globalization, this should be paid serious attention to obtain satisfactory results, especially for Indonesian who entered the category of non-English speaking country. There are four skills in English that must be learned; listening, speaking, reading, and writing. Mastering these four skills aims to enable learners in understanding and applying English actively.

Teaching English especially for students in kindergarten is seen as essential to develop children language skills in the future. Referring to the Montessori Method, there are several things that characterize this method which must be applied by teachers in schools, especially in TEYL, such as the many uses of game tools and educational games. Therefore, teachers must be creative in providing game tools related to English learning materials as well as creating educational games that can stimulate students to be interested in learning English. Teaching is done through the stages of introduction, progress, until the children are really capable (master). That is actually called a real Montessori report, which is based on how the children are able to master the tools of play that exist in the Montessori class. John and Morrow (1983: 60-64) propose five principles as the English teacher to create communicative situation in teaching and learning process as follows.

a. Know what you are doing

b. The whole is more than the sum of the parts

c. The processes are as important as the forms

d. To learn it, do it

e. Mistakes are not always a mistake

In implementing Montessori's values of an early childhood education, Maria Montessori (2002) develops a curriculum based on the children's developmental level. For the language area (language art), it contains the development of speaking, writing, reading, listening and grammar for children. Basic skills in writing and reading are developed through the use of letters from paper, sandpaper words, and achievements that allow children to connect between sounds and symbols, and express their thoughts through writing. Based on the Montessori method, language learning should refer to the following: 
a. $80 \%$ free activity and $20 \%$ of activity directed by the teacher.

b. Doing various tasks that encourage thinking about social relationship.

c. Offering opportunities for social relationships through free interaction.

d. The arguments are found by themselves, not presented by the teacher

e. The pronunciation rules are obtained through pattern recognition, not by memorizing every aspect of the curriculum involving thought.

\section{RESEARCH METHODOLOGY}

This research uses descriptive qualitative method which aims to describe the implementation of Montessori's values into Teaching English to Young Learners at Aisyiyah Kindergarten, Karanganyar. The subjects of this research are English teacher and 26 students in this school. The instruments used in this research are observation and interview. Observation is used to describe learning activities in English lesson. The researcher paid attention to students and teacher' activities, wrote some notes, and took documentation during observation. While interview was used to get spoken information about implementation of Montessori's values in TEYL, students' achievement, problems, and teacher's perception. The interview was done to five students randomly to get their opinion about English teaching and learning process. Furthermore, the information is also got from the headmaster about curriculum, teaching activities, and her perception Montessori's values in Teaching English to Young Learners. Systematically, the steps of the research also stated in the following scheme:

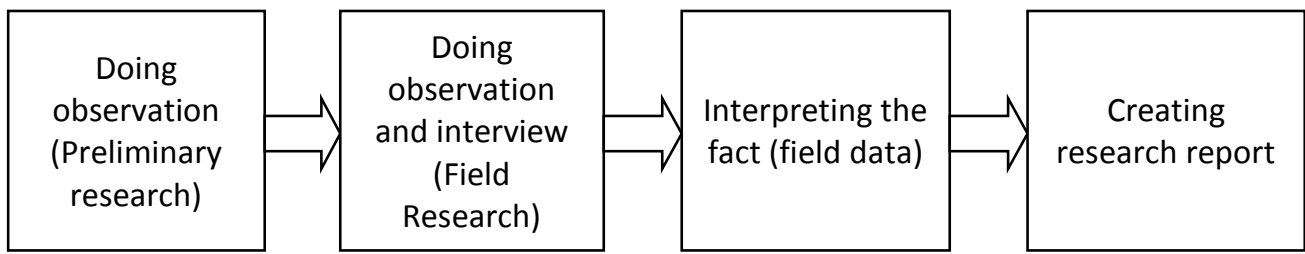

a. Doing Observation (Preliminary research)

This is the first stage to do the research. The researcher did observation about the teaching and learning process at school. The researcher also conducted interview with teacher and some students randomly to get the information about learning activities in this school. To support this preliminary research, the researcher also conducted interview to the headmaster of 
this school to get the information about curriculum used in this school. The result of preliminary research strengthens the researcher to continue doing the field research.

b. Doing Research and Interview (Field Research)

In this stage, the researcher took primary and secondary data. The primary data was taken from observation and interview, while the secondary data was taken from the existing data at school and also literature. The researcher observed the English teaching and learning process, took documentation, wrote some notes, and also recorded the interview.

c. Interpreting the Fact (Field Data) After getting the field data, the researcher interpreted the data which taken from observation and also interview with headmaster, the English teacher and 5 students randomly. This interpretation data will be used to take the findings in this research. Therefore, the researcher also analyzed the strength and weaknesss of Montessori's values in TEYL which is applied in this school.

d. Creating Research Report

This is the last step that the researcher composed research report and revealed the result of the research to public.

\section{RESULT AND DISCUSSION}

\section{English Teaching and Learning Process}

English teaching and learning process is handled by two English teachers. Students from TK A and TK $B$ level join together in this learning. The teachers provide many choices of activities to all their students, both inside and outside the classroom. Here students are free to choose their activities what they want. Students are learning by playing happily like in their own home. They move from one activity to another. One teacher handles activities in the classroom, while the other teacher is outside the classroom. In the class there are some English learning activities such as constructing a puzzle of fruits contained English material. There are also some students who are busy writing and drawing animals that are also written in English. In addition there are also some students who are playing English computer game about animals.

On the other hand outside the classroom, some students are playing snake ladder supervised by their teacher. The ladder snake that is played is a game tool that there is English material in it. The teacher will ask yes no question in English to the students who are playing the ladder snake. In addition, there are also students who are singing English song. They dance and sing alongside the music played outside the 
classroom. The song they sang contains nursery rhyme songs. All learning activities are chosen by the students themselves. The teacher only directs and supervises. Occasionally teachers also provide explanations when students ask questions. For example when doing a game in the classroom, the teacher will supervise her students one by one and answer all her students questions related to the lesson. In each activity, the students will prepare themselves. For example

when they are going to play a snake ladder, they will take the carpet shaped snake ladder and take the doll-shaped dice from the storage room. After they have finished, they will tidy it up again. This free activity is done during the learning process approximately 60 minutes. Teachers will continue to supervise their students in learning and occasionally help students who find difficult things when learning. The situation of teaching and learning process is described as follows.

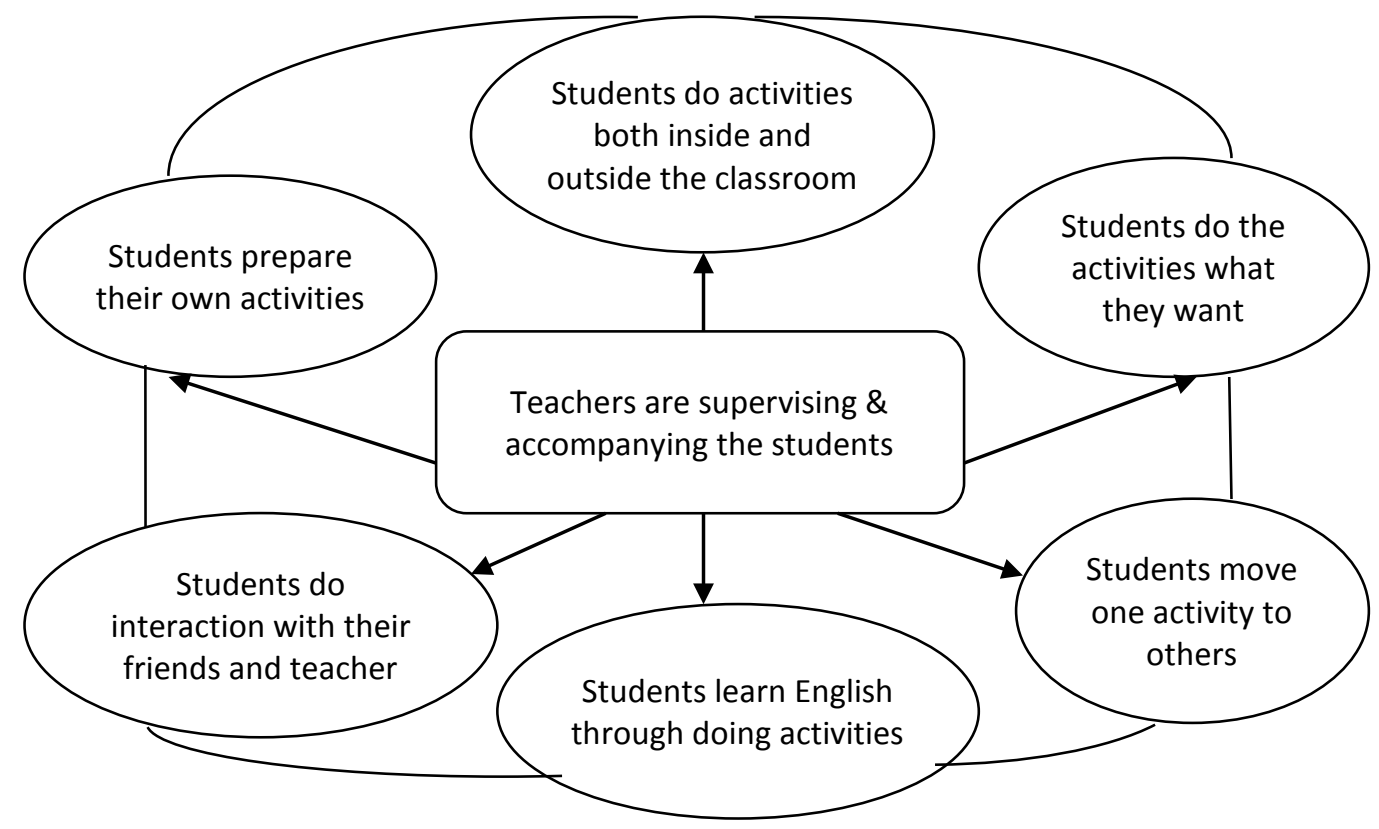

Analysis on English Teaching and Learning Process

Based on the observation when English teaching and learning process took place, the teachers mixed students from TK A and TK $B$ level in one learning activity. It teaches students to develop their emotional and social intelligence. They will interact with each other. Students from smaller levels will learn from higher level students. In addition, senior students will also appreciate students of smaller levels. In this situation, students are taught to socialize well with team work.

In the observation also noted the teachers teach independence on the students. The teachers do not give instructions but will explain 
something when asked by their students. Students can choose what learning activity they like. For example when they want to play a ladder snake, they will prepare this game themselves and when finished, they will return it to storage room. In addition, students are also taught to concentrate for example in constructing puzzle with English lesson inside. Students will try hard to solve the problem. The teachers are just watching and will end up giving feed back to their students. It teaches students to be creative, smart and innovative learners.

In addition, in the observation also seen students really enjoy all activities. They do not feel bored because they are free to choose what they want to learn. They also practice to share with friends for example when taking turns playing English computer games. Unconsciously, they are memorizing many English vocabularies through activities of their own choosing. Every activity has a theme, and everything is English material.

\section{The Strengths of Implementing} Montessori's Values in TEYL at TK Aisyiyah :

a. Students become good, creative, and innovative autonomous learner.

b. Most children enjoy English teaching and learning process. The freedom in choosing activities to learn is well. c. Combining children from different levels will shape respect and help each other.

d. This activity will teach children to be responsible, ranging from setting up their pursuit activities to completing their activities.

e. Teachers do not need to explain many things, just simply give instructions and accompany students during study

f. Students learn a lot because they move around. For example in this study, students learn vocabulary from the topics of animals, fruits, yes no question, numbers, and alphabet at one time.

The Weaknesses of Implementing Montessori's Values in TEYL at TK Aisyiyah :

a. The number of teachers is limited so they should be extra in attention to their students.

b. Children become less focused on learning in specific material because some are always move from one learning activities to others.

c. Media of learning should be created more interesting.

d. In adopting Montessori's values into TEYL, there are still many more specific Montessori methods required.

e. It is important to pay attention seriously on how students interact with one another because not all students can interact well. 
f. It is difficult to apply Montessori's values continuously, especially in English class, remembering this lesson is a foreign language that sometimes need to be explained more deeply, for instance in the subject of speaking or grammar.

\section{The Result of Interview}

Teachers argue that applying Montessori's values in teaching English to Young Learners helps students to increase students' interest and enthusiasm in learning English. It is proven that students become more spirit, especially when interacting and choosing learning activities. Students do not feel depressed while learning because they feel free to determine the learning activities they like. In addition, the independence and creativity of students will grow as well as their character building is more developed. The teacher is only a consultant when students have difficulty learning. Unbelievable, this is the process of discovery learning. This is also one of the principles they apply from Montessori's values; "Teach me how to do it", which means that teachers only help students to teach them to solve their problems. Students will solve their own problems.

On the other hand, the teachers also believe that Montessori's values that they apply are not perfect because they still have many obstacles such as limitations of teachers who are not balanced with the number of students. Furthermore, Montessori's values require teachers to be creative especially in creating media of learning, and of course it is not easy. The achievement of students is also difficult to be measured because there is no special material or testing when applying this Montessori's values.

Interviews were also conducted to five students randomly to find out their opinions about English learning. Four of the students answered that they were happy to learn English, but one student said they were not too happy and just playful but did not like learning to memorize vocabulary in English. It can be concluded that students enjoy learning English by the way their teachers teach.

\section{CONCLUSIONS}

Based on the results of the research, it is concluded that the application of Montessori's values in TEYL is able to increase students' interest and enthusiasm in learning English. Students enjoy every activity of learning and become more active, independent and responsible for what they learn. This is reinforced also from the results of interviews that have been done to teachers and 5 students. However, there are some weaknesses in applying Montessori's values in TEYL such as it is difficult to control student achievement result 
because there is no testing. Moreover, applying Montessori's values also require high creativity so that students will not get bored doing free activity any time.

\section{REFERENCES}

Aisyah, Siti. (2011). Perkembangan dan Konsep Dasar Pengembangan Anak Usia Dini, Jakarta: Universitas Terbuka.

Ary, Donald et al. 2007. Introduction to Research in Education. New York: CCBS College Publishing.

Bagby, Natalie A. 2010. A Review of the Literature, 2007 - 2009. Montessori education and practice. Journal Report.

Bathan, Olano. 2011. Montessori Method Fosters Superior Skills in Children Science. Journal Report.

Brock-Utne, B., \& Holmarsdottir, H. B. (2004) Language policies and practices in Tanzania and South Africa : Problems and challenges. International Journal of Educational Development. 24(1). 67-83. http://dx.doi.org/10.1016/j.bbr .2011.03.031

Brown, Douglas H. 2003. Language Assessment (Principles and Classroom Practices). New York: Pearson Education, Inc.

Cauler T. 2011. Toward an improved model of education: Maria Montessori, Karl Popper, and the evolutionary epistemology of human learning. Lehigh University.
Crain, W. 2004. Montessori. Encounter, 17(2), 2-4. Retrieved December 20, 2006 from EBSCO Online Database Education Research Complete. http://search.ebscohost. com/login.aspx?direct=true\&db $=$ aph \&AN $=13936267 \&$ site $=$ eho st-live

Enever, J., \& Moon, J. (2009) New global contexts for teaching primary ELT Change and challenge In J. Enever., J. Moon \& U Raman (Eds). Young learner English language policy and implementation International perspectives (pp. 5-21) Reading : Garnet Education.

Hu, Y. (2007). China's foreign language policy on primary English education. What's behind it? Language Policy, 6,359-376.

http://dx.doi.org/10.1007/s109 93-007-9052-9

Montessori, M. (1967). The discovery of the child. New York: Ballantine. Retrieved November 29, 2007, from http://www.montessori.edu

Montessori, M. 2002. the Montessori method. New York: Dover Publications.

Morrow, K. 1983. "Principles of Communication Methodology". In Johnson, K. And Morrow, K. Communication in the Classroom: Application and Methods for A Communicative Approach. Longman House, Burnt Mill, Harlow, Essex CM20 2JE, England: Longman Group Limited 
Patmonodewo, Soemirat. 2001.

http://www.scribd.com/doc/279553 Pendidikan Anak Prasekolah. 82/PANDANGAN-MONTESSORI Jakarta: Rineka Cipta (accessed 5/10/2017)

Piccolo, Louanne. 2010. TEYLTeaching Young Children English. Journal Suite 101, April $8^{\text {th }}$ 2010. http://www.suite101.com/con tent/what-is-teyl--a-definitiona223800. Retrieved on November $15^{\text {th }} 2010$

Pinter, A, Teaching Young Learners (University Press), Oxford, 2006

Scoot, Wendy A. and Lisbeth $\mathrm{H}$. Ytreberg. 1993. Teaching English to Children. New York: Longman

Sujiono, Yuliani Nurani. 2009. Konsep Dasar Pendidikan Anak Usia Dini. Jakarta. PT Indeks.

UU RI NO 20 TH 2003 SISDIKNAS

Yulianti, Fitri. 2005. Penggunaan Beragam Media Bermain sebagai Pendukung Keberhasilan Belajar Bahasa Inggris di TK. Semarang: Unpublished paper

Keterampilan Psikomotorik
Berbahasa Inggris pada Anak
Usia SD melalui Media
Playground. Semarang:
Unpublished paper
http://kartikarinakit.wordpress.com/
$\frac{2013 / 01 / 30 / \text { filsafat-ilmu- }}{\text { dalam-kajian-paud/ } \quad \text { (accessed }}$
5/10/2017)
$\frac{\text { http://montessori- }}{\text { education.net/sekolah- }}$
$\frac{\text { montessori-\%E2\%80\%93- }}{\text { metode-sekolah- }}$
$\frac{\text { montessori.html }}{5 / 10 / 2017) \quad \text { (accessed }}$

